\title{
Physical fractionation of organic carbon in areas under different land uses in the Cerrado
}

\author{
Adilson A. Costa ${ }^{1}$, Bruno de O. Dias ${ }^{1}$, Vânia da S. Fraga ${ }^{1}$, Charles C. Santana ${ }^{2}$, Thalita F. Sampaio ${ }^{3}$ \& \\ Núbia da Silva ${ }^{4}$ \\ ${ }^{1}$ Universidade Federal da Paraíba/Centro de Ciências Agrárias/Programa de Pós-Graduação em Ciência do Solo. Areia, PB, Brasil. E-mail: agroadalves@gmail.com \\ (Corresponding author) - ORCID: 0000-0002-6773-9219; brunodiascca@gmail.com - ORCID: 0000-0003-1259-5921; vfraga@cca.ufpb.br - ORCID: 0000-0003- \\ 0181-0753 \\ ${ }^{2}$ Universidade Federal de Viçosa/Centro de Ciências Agrárias/Programa de Pós-Graduação em Engenharia Agrícola. Viçosa, MG, Brasil. E-mail: \\ santana.agr@hotmail.com - ORCID: 0000-0002-3773-7415 \\ ${ }^{3}$ Faculdade Arnaldo Horário Ferreira/Colegiado de Agronomia. Luís Eduardo Magalhães, BA, Brasil. E-mail: thalitafs2003@yahoo.com.br - ORCID: \\ 0000-0001-7867-4097 \\ ${ }^{4}$ Universidade do Estado da Bahia/Departamento de Ciências Humanas. Barreiras, BA, Brasil. E-mail: nubiaetnobio@gmail.com - ORCID: 0000-0001-8558-8250
}

\begin{abstract}
With the expansion of agricultural production, native Cerrado areas are replaced with other forms of land use. Thus, the objective of this study was to evaluate changes in the physical fractionation of organic carbon (C) in areas under different forms of land use in the Cerrado. The treatments, with five repetitions, corresponded to the following forms of use: area under conventional tillage, area under pasture plantation, area under eucalyptus plantation and area under native Cerrado vegetation, at the depths of $0-5$, 5-10, 10-15 and 15-20 cm in the municipality of Luis Eduardo Magalhães, BA, Brazil. The highest C contents and stocks were found in the eucalyptus area, which were equal to those of the area under native Cerrado vegetation, while particulate $C$ stocks were higher in the area under pasture at the depth up to $10 \mathrm{~cm}$, not differing from the area under native Cerrado. Pasture and eucalyptus had positive effect on $\mathrm{C}$ management index, regardless of depth.
\end{abstract}

Key words: eucalyptus, carbon management index, pasture

\section{Fracionamento físico do carbono orgânico em áreas sob diferentes usos do solo no Cerrado}

RESUMO: Com a expansão da produção agrícola, há a substituição de áreas de Cerrado nativo por outras formas de uso do solo. Assim, objetivou-se avaliar alterações no fracionamento físico do carbono orgânico em áreas submetidas a diferentes usos do solo no Cerrado. Os tratamentos, com cinco repetições, corresponderam às seguintes formas de uso: área sob plantio convencional, área sob plantio de pastagem, área sob plantio de eucalipto e área sob vegetação nativa de Cerrado nas profundidades de 0-5, 5-10, 10-15 e 15-20 cm no munícipio de Luís Eduardo Magalhães, BA. Os maiores teores e estoques de carbono foram encontrados para a área de eucalipto, iguais à área sob vegetação nativa de Cerrado. Já os estoques de carbono particulado foram superiores na área sob pastagem na profundidade de até $10 \mathrm{~cm}$, não diferenciando da área sob Cerrado nativo. A pastagem e o eucalipto apresentaram efeito positivo no índice de manejo do carbono, independentemente da profundidade.

Palavras-chave: eucalipto, índice de manejo de carbono, pastagem 


\section{INTRODUCTION}

With the opening of new agricultural frontiers in the Cerrado, an area with great agricultural potential, the adoption of agroecosystems with crops, replacing natural ecosystems, has caused reduction in the content of soil organic carbon (OC), as a result of the decrease in the supply of organic matter (Frazão et al., 2010; Hickmann \& Costa, 2012). However, the impact of different forms of land use causes changes in the dynamics of organic fractions of the soil, directly affecting the maintenance of its agricultural sustainability, as shown by Loss et al. (2011), who worked with carbon (C) management index, in areas under different forms of use, and verified that no-tillage promotes greater sustainability.

In the Cerrado, native forest has been replaced by other forms of land use, such as pasture, eucalyptus and different management systems. Studies have demonstrated a reduction in soil C stocks with the planting of pasture (Dortzbach et al., 2015). However, there are still divergences among the observed data because Guo \& Gifford (2002), working with literature data relating $\mathrm{C}$ stock and land use changes, observed an increase of up to $8 \%$ of $\mathrm{C}$ in areas converted from forests to pasture. For many authors, low stocks may be related to inadequate management adopted in pastures (Salimon et al., 2007; Dortzbach et al., 2015). Research results have also shown that $\mathrm{C}$ stocks can increase in soils under eucalyptus plantations when they are well managed (Tchienkoua \& Zeach, 2004). Moreover, organic matter residues promote numerous benefits to the soil-plant system, being essential in low-C agriculture (Costa et al., 2014), besides improving nutrient cycling, cation exchange capacity, water retention and C stocks (Vieira et al., 2009; Mendonça et al., 2013). Lima et al. (2016) observed that the no-tillage system increased the content of $\mathrm{C}$ associated with the mineral fraction of the soil when compared to conventional planting. Moreover, these authors verified a strong influence of the incorporation of organic residues on particulate C.

The objective of this study was to evaluate the changes in the physical fractionation of organic $\mathrm{C}$ in areas under different soil uses in the Cerrado.

\section{Material AND Methods}

The research was carried out in Oxisols, deep and well-drained in areas under four different land use in the municipality of Luís Eduardo Magalhães - BA under geographical coordinates $11^{\circ} 51^{\prime} 8^{\prime \prime}$ and $12^{\circ} 33^{\prime} 50^{\prime \prime} \mathrm{S}$ and $45^{\circ} 37^{\prime} 50^{\prime \prime}$ e $46^{\circ} 23^{\prime} 35^{\prime \prime} \mathrm{W}$, with an altitude of $763 \mathrm{~m}$. The climate of region is classified as Aw according to Koppen and Geiser with temperatures varying between 22 to $30^{\circ} \mathrm{C}$. The anual rainfall is greater than $1,000 \mathrm{~mm}$ and the rain period is frim october to march.

Four areas with different forms of use were studied: area under conventional planting (ACP); area under pasture planting (APA); area under eucalyptus plantation (AEU); and area under native Cerrado sensu stricto (ANC). Native Cerrado vegetation, with no history of any exploitation or human interference. The history of the áreas, as well as their coordinates, were described in detail by Costa et. al (2020).

In each study area, disturbed samples were collected at a depth of $0-20 \mathrm{~cm}$ using an auger and taken to the Soil Chemistry and Physics Laboratory of the Universidade do Estado da Bahia - UNEB, Brazil, where they were air dried, pounded to break up clods and passed through a 2-mm-mesh sieve to obtain air-dried fine earth (ADFE). After the disturbed samples were prepared (ADFE), chemical characterization and particle-size analysis were performed (EMBRAPA, 2017) (Tables 1 and 2).

In each area, a plot of 1 ha $(100 \times 100 \mathrm{~m})$ was selected and five mini profiles with dimensions of approximately $1.5 \mathrm{~m}$ length $\mathrm{x} 1 \mathrm{~m}$ width $\mathrm{x} 0.3 \mathrm{~m}$ depth were opened, randomly chosen. In each mini profile, disturbed samples were collected using an auger at depths of 0-5, 5-10, 10-15 and 15-20 cm, air dried, pounded to break up clods and passed through a 2-mm-mesh sieve to obtain ADFE for the determination of physical fractionation.

Organic C contents were quantified by wet oxidation of organic matter with potassium dichromate in sulfuric acid medium, following the method of EMBRAPA (2017).

C stocks were obtained through the correction of soil mass using the soil layer and equivalent mass based on the reference soil mass (Ellert et al., 2001). The equivalent mass was calculated considering the relative soil mass in the different forms of use by Eq. 1 .

$$
\text { Msoil }=\text { BD T A }
$$

where:

Msoil - soil mass, $\mathrm{Mg} \mathrm{ha}^{-1}$;

Table 2. Physical characterization of the soil of the study areas subjected to different land uses, at the depth of 0-20 cm

\begin{tabular}{|c|c|c|c|c|c|}
\hline \multirow{3}{*}{$\begin{array}{l}\text { Land } \\
\text { use }\end{array}$} & \multicolumn{3}{|c|}{ Particle size } & \multirow{3}{*}{$\begin{array}{c}\text { Textural } \\
\text { classification }\end{array}$} & \multirow{3}{*}{$\begin{array}{l}\text { Bulk density } \\
\left(\mathrm{kg} \mathrm{dm}^{-3}\right)\end{array}$} \\
\hline & Sand & Silt & Clay & & \\
\hline & \multicolumn{3}{|c|}{$\left(\mathrm{g} \mathrm{kg}^{-1}\right)$} & & \\
\hline ACP & 760 & 30 & 210 & Sandy clay loam & 1.28 \\
\hline APA & 749 & 32 & 219 & Sandy clay loam & 1.30 \\
\hline EUC & 716 & 40 & 244 & Sandy clay loam & 1.10 \\
\hline ANC & 714 & 41 & 245 & Sandy clay loam & 1.08 \\
\hline
\end{tabular}

ACP - Area under conventional planting; APA - Area under pasture plantation; EUC Area under Eucalyptus plantation; ANC - Area under native Cerrado

Table 1. Chemical characterization of the soil of the study areas subjected to different land uses, at the depth of $0-20 \mathrm{~cm}$

\begin{tabular}{|c|c|c|c|c|c|c|c|c|c|}
\hline \multirow{3}{*}{$\begin{array}{l}\text { Land } \\
\text { uses }\end{array}$} & \multicolumn{8}{|c|}{ Chemical attributes } & \multirow{3}{*}{$\begin{array}{c}\mathrm{OM} \\
\left(\text { dag } \mathrm{kg}^{-1}\right)\end{array}$} \\
\hline & \multirow{2}{*}{$\begin{array}{c}\mathrm{pH} \\
\left(\mathrm{H}_{2} \mathrm{O}\right)\end{array}$} & $\mathrm{Ca}$ & $\mathrm{Mg}$ & Al & $\mathrm{H}+\mathrm{Al}$ & $\mathbf{P}$ & $\mathrm{K}$ & \multirow{2}{*}{$\begin{array}{l}\mathbf{V} \\
\%\end{array}$} & \\
\hline & & \multicolumn{4}{|c|}{$\left(\mathrm{cmol}_{\mathrm{c}} \mathrm{kg}^{-1}\right)$} & \multicolumn{2}{|c|}{$\left(\mathrm{mg} \mathrm{kg}^{-1}\right)$} & & \\
\hline ACP & 6.3 & 2.7 & 0.7 & 0.0 & 1.3 & 48.8 & 54.6 & 73.1 & 1.7 \\
\hline APA & 6.2 & 2.6 & 0.7 & 0.0 & 1.5 & 55.6 & 35.8 & 69.3 & 1.6 \\
\hline EUC & 5.4 & 2.3 & 0.6 & 0.0 & 1.7 & 10.8 & 15.6 & 63.3 & 1.8 \\
\hline ANC & 5.1 & 1.2 & 0.4 & 0.4 & 3.2 & 7.6 & 10.9 & 33.7 & 1.7 \\
\hline
\end{tabular}

ACP - Area under conventional planting; APA - Area under pasture plantation; EUC - Area under Eucalyptus plantation; ANC - Area under native Cerrado 
$\mathrm{BD}$ - bulk density, $\mathrm{Mg} \mathrm{m}^{-3}$;

$\mathrm{T}$ - thickness, $\mathrm{m}$; and,

A - area, $10,000 \mathrm{~m}^{2}$.

After defining the soil mass, the area under native Cerrado (ANC) was considered as a reference area. Then, the soil layers to be added or subtracted were calculated in order to equal the soil masses of the treatments. Eq. 2 was used to calculate the layers to be added or subtracted.

$$
\operatorname{Tad} / \mathrm{sub}=\frac{(\text { Mref }- \text { Marea }) \text { Fha }}{\text { BD }}
$$

where:

$\mathrm{Tad} / \mathrm{sub}$ - thickness of the soil layer to be added $(+)$ or subtracted (-), m;

Mref - equivalent soil mass of the reference area, ANC, $\mathrm{Mg} \mathrm{ha}^{-1}$;

Marea - equivalent soil mass of the area, $\mathrm{Mg} \mathrm{ha}^{-1}$;

Fha - factor of conversion from ha to $\mathrm{m}^{2}, 0.0001 \mathrm{ha} \mathrm{m}^{-2}$; and,

$\mathrm{BD}$ - bulk density, $\mathrm{Mg} \mathrm{m}^{-3}$.

C stocks in equivalent mass were obtained by Eq. 3:

$$
\text { Stock }=\text { cc BD }(\mathrm{T} \pm \mathrm{Tad} / \mathrm{sub}) \mathrm{A} \text { Fkg }
$$

where:

Stock - stock of C per unit of area in equivalent layer, $\mathrm{Mg} \mathrm{ha}^{-1}$;

CC - content of $\mathrm{C}, \mathrm{g} \mathrm{kg}^{-1}$;

$\mathrm{BD}$ - bulk density, $\mathrm{Mg} \mathrm{m}^{-3}$;

$\mathrm{T}$ - thickness of the studied soil layer, $\mathrm{m}$;

$\mathrm{Tad} / \mathrm{sub}=$ thickness of the soil layer to be added $(+)$ or subtracted (-), m;

A - area, considering 1 ha, i.e. $10,000 \mathrm{~m}^{2}$; and,

Fkg - factor of conversion from $\mathrm{kg}$ to $\mathrm{Mg}, 0.001 \mathrm{Mg} \mathrm{ha}^{-1}$.

The granulometric physical fractionation was determined according to the methodology of Cambardella \& Elliot (1992). In the procedure, $20 \mathrm{~g}$ of ADFE were weighed, and $60 \mathrm{~mL}$ of sodium hexametaphosphate solution $\left(5 \mathrm{~g} \mathrm{~L}^{-1}\right)$ were added. The samples were homogenized for $16 \mathrm{~h}$ in horizontal shaker and, after this step, the samples were sieved through a $53-\mu \mathrm{m}$-mesh sieve. The material retained on the sieve consists of particulate organic $\mathrm{C}$ (OCp), associated with the sand fraction, and the material that passed through the sieve is called organic $\mathrm{C}$ associated with silt + clay (OCam). All the material retained on the sieve was transferred to a Petri dish and dried in an oven $\left(50{ }^{\circ} \mathrm{C}\right)$ for $24 \mathrm{~h}$. After this step, the material was ground in porcelain mortar and the organic $\mathrm{C}$ content was determined according to the methodology of EMBRAPA (2017). The OC content in OCam was obtained by difference between soil OC and OCp.

Carbon management index (CMI) was estimated using Eq. 4:

$$
\mathrm{CMI}=\mathrm{CSI} \text { LI } 100
$$

where:

CSI - carbon stock index, calculated through the ratio between the $\mathrm{C}$ stocks of the areas with different forms of land use (Ctreat) and the reference area (Cref), Eq. 5, considering in this case the area under native Cerrado (ANC):

$$
\mathrm{CSI}=\frac{\text { Ctreat }}{\text { Cref }}
$$

where:

LI - organic matter lability index, which is determined by the ratio between the lability of areas with different forms of land use (Ltreat) and the lability of the reference area (Lref) $(\mathrm{LI}=$ Ltreat/Lref).

Lability (L) was determined using Eq. 6:

$$
\mathrm{L}=\frac{\text { OCpStock }}{\text { OCamStock }}
$$

OCpStock - stocks of particulate organic carbon; and,

OCamStock - stocks of organic carbon associated with silt + clay (Blair et al., 1995).

Statistical analysis of the data was performed using a completely randomized design, with five repetitions. Analysis of variance was applied and the means were compared by Tukey test at $\mathrm{p} \leq 0.05$, using the software program SAS (2003).

\section{RESULTS AND Discussion}

Compared to the area under native Cerrado vegetation (ANC), the conventional planting (ACP) and the pasture (APA) reduced the total organic $\mathrm{C}$ (TOC) contents by approximately 32 and $8 \%$, respectively, at the depth of up to $5 \mathrm{~cm}$ (Table 3 ). On the other hand, eucalyptus cultivation (AEU) did not differ from ANC. TOC decreased according to the depth for APA. The differences of TOC in AEU compared to the other land uses with soil turning are explained by root exudation. In addition, the eucalyptus has been planted for nine years, and in this period there has been a production of biomass that is deposited on the soil, which increases the soil organic matter content and, consequently, leads to greater storage of TOC. On the other hand, the reduction in TOC that occurs in conventional use and pasture is related to soil degradation because, for Guimarães et al. (2014), degradation occurs through the reduction in the input or recycling of organic materials and greater soil disturbance.

The labile fraction, defined as particulate organic C (OCp) varied from 0.31 to $1.15 \mathrm{~g} \mathrm{~kg}^{-1}$ at the depths evaluated (Table 3 ), but there was no difference in their values when ANC is compared to APA and AEU at a depth of up to $20 \mathrm{~cm}$. The lowest values were found for ACP, with reductions of 19, 7 and $4 \%$ in comparison to APA, AEU and ANC, respectively, up to $5 \mathrm{~cm}$ depth. This result corroborates other studies which found that the main fraction of soil organic matter (SOM) modified by management is the particulate fraction, being the most effective and sensitive to evaluate the changes in TOC contents due to the different land uses, especially in the first centimeters (Loss et al., 2011; Galdo et al., 2009). The highest values of OCp may be related to the longer and larger roots 
Table 3. Total organic carbon (TOC), particulate organic carbon associated with organic matter (OCp), organic carbon associated with the mineral fraction (OCam) and percentages of OCp and OCam in an Oxisol subjected to different land uses at depths of $0-5,5-10,10-15$ and $15-20 \mathrm{~cm}$ in the Cerrado

\begin{tabular}{|c|c|c|c|c|c|}
\hline \multirow{2}{*}{$\begin{array}{l}\text { Land } \\
\text { use }\end{array}$} & TOC & OCp & OCam & OCp/TOC & OCam/TOC \\
\hline & \multicolumn{3}{|c|}{$\left(\mathrm{g} \mathrm{kg}^{-1}\right)$} & \multicolumn{2}{|c|}{$(\%)$} \\
\hline & & & epth, 0-5 cm & & \\
\hline ACP & $9.12 \pm 0.22 c$ & $0.93 \pm 0.03 c$ & $8.19 \pm 0.13 c$ & $10.19 \pm 0.21$ & $89.80 \pm 0.20$ \\
\hline APA & $12.40 \pm 0.32 b$ & $1.15 \pm 0.11 \mathrm{a}$ & $11.25 \pm 0.49 b$ & $9.27 \pm 0.31$ & $90.72 \pm 0.18$ \\
\hline AEU & $12.13 \pm 0.37 a b$ & $1.00 \pm 0.03 \mathrm{a}$ & $11.13 \pm 0.37 b$ & $8.24 \pm 0.13$ & $91.75 \pm 0.31$ \\
\hline \multirow[t]{2}{*}{ ANC } & $13.44 \pm 0.50 \mathrm{a}$ & $0.97 \pm 0.04 \mathrm{a}$ & $12.47 \pm 0.51 \mathrm{a}$ & $7.21 \pm 0.36$ & $92.78 \pm 0.32$ \\
\hline & \multicolumn{5}{|c|}{ Depth, $5-10 \mathrm{~cm}$} \\
\hline ACP & $10.07 \pm 0.23 b$ & $0.67 \pm 0.02 b$ & $9.4 \pm 0.21 b$ & $6.65 \pm 0.14$ & $93.35 \pm 0.30$ \\
\hline APA & $9.14 \pm 0.32 b$ & $0.85 \pm 0.07 a$ & $8.29 \pm 0.36 b$ & $9.29 \pm 0.89$ & $91.70 \pm 0.35$ \\
\hline AEU & $10.82 \pm 0.21 \mathrm{a}$ & $0.75 \pm 0.05 a$ & $10.06 \pm 0.22 \mathrm{a}$ & $6.93 \pm 0.46$ & $92.97 \pm 0.25$ \\
\hline \multirow[t]{2}{*}{ ANC } & $11.70 \pm 0.36 \mathrm{a}$ & $0.70 \pm 0.03 a b$ & $11.0 \pm 0.38 \mathrm{a}$ & $5.98 \pm 0.41$ & $94.02 \pm 0.29$ \\
\hline & \multicolumn{5}{|c|}{ Depth, $10-15 \mathrm{~cm}$} \\
\hline ACP & $8.94 \pm 0.14 b$ & $0.47 \pm 0.02 a$ & $8.46 \pm 0.14 b$ & $5.25 \pm 0.22$ & $94.63 \pm 0.28$ \\
\hline APA & $8.84 \pm 0.20 b$ & $0.55 \pm 0.04 \mathrm{a}$ & $8.29 \pm 0.19 b$ & $6.22 \pm 0.38$ & $93.78 \pm 0.32$ \\
\hline AEU & $10.02 \pm 0.12 \mathrm{a}$ & $0.46 \pm 0.02 \mathrm{a}$ & $9.55 \pm 0.12 \mathrm{a}$ & $4.59 \pm 0.18$ & $95.30 \pm 0.18$ \\
\hline \multirow[t]{2}{*}{ ANC } & $10.28 \pm 0.50 \mathrm{a}$ & $0.46 \pm 0.02 \mathrm{a}$ & $9.81 \pm 0.50 \mathrm{a}$ & $4.47 \pm 0.25$ & $95.52 \pm 0.31$ \\
\hline & \multicolumn{5}{|c|}{ Depth, $15-20 \mathrm{~cm}$} \\
\hline $\mathrm{ACP}$ & $7.08 \pm 0.32 b$ & $0.33 \pm 0.03 a$ & $6.75 \pm 0.34 b$ & $4.68 \pm 0.58$ & $95.34 \pm 0.30$ \\
\hline APA & $7.66 \pm 0.55 b$ & $0.37 \pm 0.03 a$ & $7.28 \pm 0.57 b$ & $4.83 \pm 0.76$ & $95.04 \pm 0.21$ \\
\hline AEU & $8.94 \pm 0.24 a$ & $0.34 \pm 0.02 a$ & $8.60 \pm 0.23 a$ & $3.80 \pm 0.14$ & $96.19 \pm 0.18$ \\
\hline ANC & $8.84 \pm 0.53 a$ & $0.31 \pm 0.14 a$ & $8.52 \pm 0.52 \mathrm{a}$ & $3.51 \pm 0.14$ & $96.38 \pm 0.29$ \\
\hline
\end{tabular}

ACP - Area under conventional planting (succession of soybean/maize/cotton); APA - Area under pasture in the last three years; AEU - Area under eucalyptus with 9 years; ANC - Area under native vegetation of Cerrado sensu stricto. Values \pm refer to the standard error of the mean

found in ANC and AEU, mainly at a depth of up to $10 \mathrm{~cm}$. Although AEU has a larger amount of TOC compared to ACP, there is a higher decomposition rate with only $8.24,6.93,4.59$ and $3.88 \%$ in labile form at the depths of $0-5,5-10,10-15$ and $15-20 \mathrm{~cm}$, respectively.

In general, there was a reduction in OCp content in subsurface, which is considered normal, as the TOC also decreased at the greatest soil depths. Similar results have also been found by Guimarães et al. (2014) and Tesfaye et al. (2016).

In relation to the $\mathrm{C}$ associated with minerals (OCam), it is observed that AEU increased its contents from the depth of 5 to $20 \mathrm{~cm}$, compared to ACP and APA, equaling the ANC. On the other hand, ACP was along with the lowest contents at the depth of $0-5 \mathrm{~cm}$ (Table 3 ). This was possibly due to the turning of the soil, carried out constantly in the production system, which results in breakage of soil particles and greater exposure of organic matter to decomposing agents.

Table 3 shows that most of the OCam has values between 89.80 and $96.38 \%$. In general, there is little variation between the different land uses, except for APA, at a depth of 5 to $15 \mathrm{~cm}$, which is explained by the short periods of residue incorporation (Schiavo et al., 2011).

The stocks of C (CStock), particulate organic C (OCpStock) and organic $\mathrm{C}$ associated with minerals (OCamStock) underwent changes due to the different land uses evaluated (Table 4). The conventional systems (ACP and APA) reduce soil CStock, while practices with less or total absence of soil turning (AEU and ANC) increase it at all depths evaluated. Similar results were found by Guareschi et al. (2012).

CStock in ANC and AEU did not differ, with values ranging from 6.42 to $8.47 \mathrm{Mg} \mathrm{ha}^{-1}$ and from 6.47 to $7.77 \mathrm{Mg} \mathrm{ha}^{-1}$, respectively, but were higher than those of ACP and APA at all depths (Table 4). The retention time of the residues on soil surface in AEU increases $\mathrm{C}$ stocks in the soil and, additionally,
Table 4. Stocks of total organic carbon (TOCStock) and particulate organic carbon (OCpStock) and complexed organic carbon (OCamStock) in an Oxisol subjected to different land uses at depths of 0-5, 5-10, 10-15 and 15-20 cm in the Cerrado

\begin{tabular}{|c|c|c|c|}
\hline \multirow{2}{*}{$\begin{array}{l}\text { Land } \\
\text { use }\end{array}$} & CStock & OCpStock & OCamStock \\
\hline & \multicolumn{3}{|c|}{$\left(\mathrm{Mg} \mathrm{ha}^{-1}\right)$} \\
\hline & \multicolumn{3}{|c|}{ Depth, 0-5 cm } \\
\hline ACP & $6.95 \pm 0.04 b$ & $0.70 \pm 0.02 b$ & $7.74 \pm 0.31 b$ \\
\hline APA & $7.58 \pm 0.06 b$ & $0.88 \pm 0.09 a$ & $8.63 \pm 0.39 a$ \\
\hline AEU & $7.77 \pm 0.12 \mathrm{a}$ & $0.65 \pm 0.02 b$ & $7.40 \pm 0.43 b$ \\
\hline ANC & $8.47 \pm 0.07 \mathrm{a}$ & $0.60 \pm 0.01 b$ & $7.85 \pm 0.59 b$ \\
\hline \multicolumn{4}{|c|}{ Depth, $5-10 \mathrm{~cm}$} \\
\hline ACP & $6.87 \pm 0.05 b$ & $0.55 \pm 0.02 b$ & $7.64 \pm 0.23 b$ \\
\hline APA & $6.94 \pm 0.04 b$ & $0.72 \pm 0.06 a$ & $8.01 \pm 0.38 a$ \\
\hline AEU & $7.35 \pm 0.13 a$ & $0.54 \pm 0.02 b$ & $7.33 \pm 0.24 b$ \\
\hline ANC & $7.97 \pm 0.05 \mathrm{a}$ & $0.44 \pm 0.02 b$ & $7.52 \pm 0.47 b$ \\
\hline \multicolumn{4}{|c|}{ Depth, $10-15 \mathrm{~cm}$} \\
\hline ACP & $6.44 \pm 0.05 b$ & $0.39 \pm 0.01 \mathrm{ab}$ & $7.07 \pm 0.26 a$ \\
\hline APA & $6.36 \pm 0.01 b$ & $0.45 \pm 0.03 a$ & $6.87 \pm 0.21 a$ \\
\hline AEU & $7.22 \pm 0.15 a$ & $0.33 \pm 0.02 b$ & $7.02 \pm 0.16 a$ \\
\hline ANC & $7.42 \pm 0.04 \mathrm{a}$ & $0.33 \pm 0.01 \mathrm{~b}$ & $7.08 \pm 0.29 a$ \\
\hline \multicolumn{4}{|c|}{ Depth, $15-20 \mathrm{~cm}$} \\
\hline ACP & $5.12 \pm 0.04 b$ & $0.28 \pm 0.02 \mathrm{a}$ & $5.81 \pm 0.31 a$ \\
\hline APA & $5.96 \pm 0.01 b$ & $0.29 \pm 0.02 a$ & $5.91 \pm 0.49 a$ \\
\hline AEU & $6.47 \pm 0.12 \mathrm{a}$ & $0.24 \pm 0.02 b$ & $6.28 \pm 0.23 a$ \\
\hline ANC & $6.42 \pm 0.05 a$ & $0.22 \pm 0.01 b$ & $6.19 \pm 0.49 a$ \\
\hline
\end{tabular}

for Srinivasan et al. (2012) the fraction of soil organic matter physically protects $\mathrm{C}$ from degradation, as it contains a more recalcitrant material.

Regardless of the studied depths, the OCpStock obtained in APA was higher than those found under the other forms of land use, but it did not differ from that of ACP below $0.10 \mathrm{~m}$. The amount of roots mainly in the surface layer from the pasture may have contributed to the increase in OCp contents 
and, consequently, in OCpStock, which favor lower losses of $\mathrm{C}$ in the soil, because the labile SOM will be more physically protected due to the formation of aggregates. However, the agricultural practices based on soil turning in ACP reduce the OCp contents and, thus, the values of OCpStock at the depth of up to $10 \mathrm{~cm}$.

In this case, OCpStock proved to be efficient to differentiate the forms of land use, especially in the surface layer, where there is direct influence of soil management. These results corroborate other studies which found that the main fraction of SOM modified by management is the particulate fraction (OCp), especially in the first centimeters of the soil (Loss et al., 2011; Guimarães et al., 2014).

Regarding OCamStock at the depths of 0-5 and 5-10 cm, there was a significant difference caused by land use (Table 4). However, at depths below $10 \mathrm{~cm}$ there was no difference between the areas. At depths of up to $10 \mathrm{~cm}$, the highest OCamStock occurred in APA with Brachiaria, while at the same depths, the other areas stood out with the lowest stocks of $\mathrm{C}$ in the mineral fraction of the soil. Similar results were found by Schiavo et al. (2011), who studied C in the different compartments in an Oxisol and found the highest contents of $\mathrm{C}$ associated with minerals of the clay + silt fractions in areas under Brachiaria and maize planting at a depth of up to $20 \mathrm{~cm}$ and the lowest contents in areas under native Cerrado vegetation at a surface depth of up to $5 \mathrm{~cm}$.

At the depth below $10 \mathrm{~cm}$, there was no significant difference between the studied areas, and these results are considered normal because, generally, OCamStock is the variable with the smallest changes caused by different management systems (Bayer et al., 2004).

The values of $\mathrm{C}$ stock index (CSI) in ACP observed at the depths demonstrate equality, considering their intervals, while in APA, considering the absolute values, the highest values were found at the surface depth of $0-5 \mathrm{~cm}$. For AEU, there were increasing values along the soil depth, with some of them above 0.80 (Figure 1A).

The lability index (LI) relates the lability of soil organic matter with areas cultivated with native Cerrado vegetation. LI values were equal for APA at all depths in comparison to the other land uses, considering their intervals (Figure 1B). At a depth of 5-10 cm, the area with Brachiaria had higher LI, with values of approximately 1.7 . The changes that occurred in LI are due to the form of use adopted with their respective managements, thus demonstrating changes in SOM dynamics. In APA, organic residues come from the contribution of the root system, which in turn is more prone to decomposition. Similar results were found by Schiavo et al. (2011) in a Cerrado Oxisol.

The carbon management index (CMI) measures the changes in TOC stocks, and values below 100 are negative indications of the practices on organic matter, thus compromising soil quality (Blair et al., 1995; Dona, 2005). The highest values of CMI occurred in APA and AEU, which were higher than 100 (Figure 1C). In both areas, higher CMI is observed at a depth of 5-10 cm. However, in ACP, the values of CMI were low (below 100), indicating a reduction in soil quality, which is probably associated with soil tillage practices such as plowing
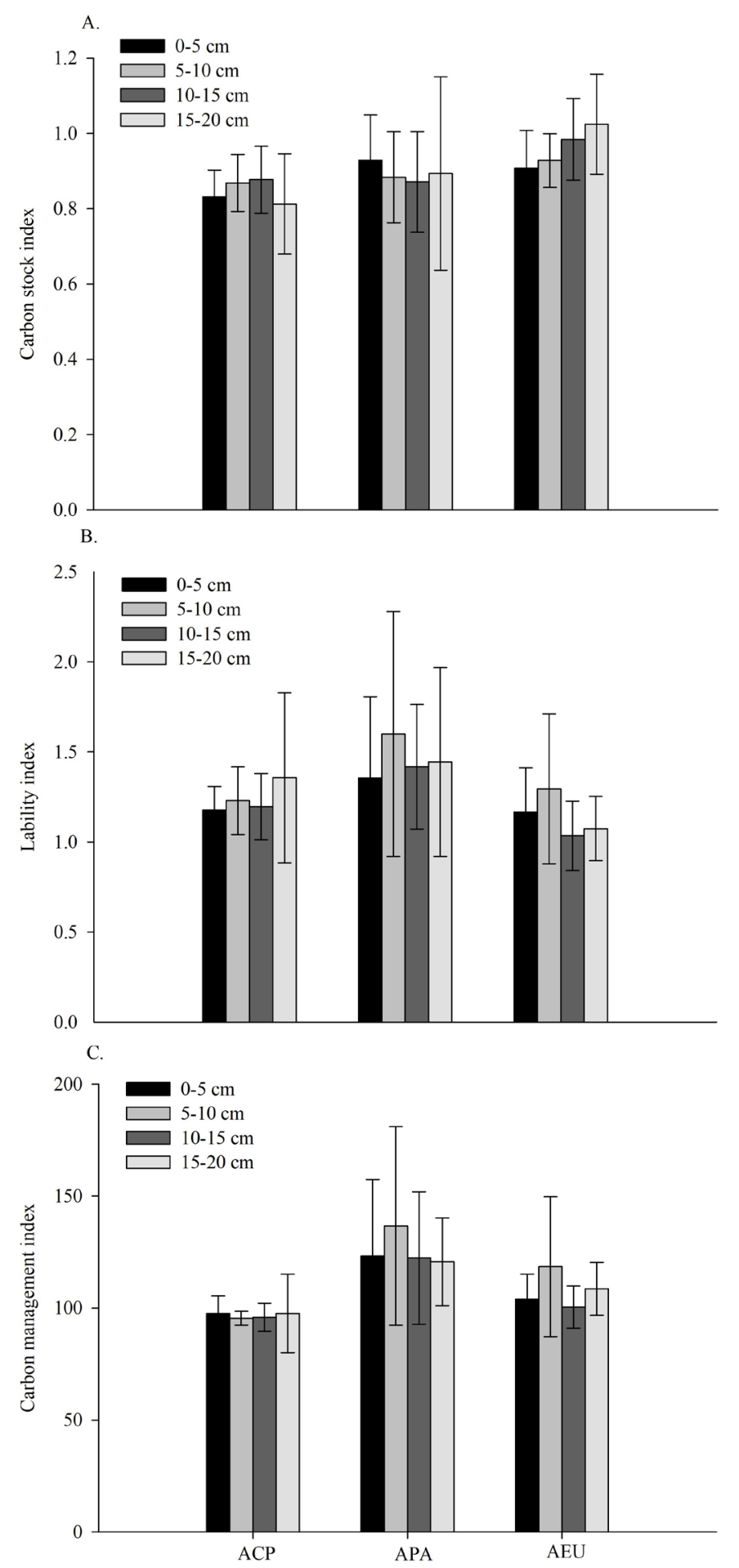

ACP - Area under conventional planting (succession of soybean/maize/cotton), APA - Area under pasture in the last three years; AEU - Area under eucalyptus with 9 years; ANC - Area under native vegetation of Cerrado sensu stricto; Values \pm refer to the standard error of the mean

Figure 1. Carbon stock index - CSI (A), lability index - LI (B) and carbon management index - CMI (C) in an Oxisol under different land uses in the Cerrado

and harrowing. Therefore, the change in land use from native Cerrado vegetation to conventional planting negatively affects soil quality, not contributing to the increase of soil C, which can be verified through the CMI. It is worth pointing out that AEU has a long period of implementation, about nine years, which contributed to increasing the CMI mainly at the depths of 5 to 10 and 15 to $20 \mathrm{~cm}$. These results, found in the areas under pasture and eucalyptus, come from the lability of C (LC), 
which had higher sensitivity, with amplitudes greater than 0.89 and 0.91 , respectively in the area under native Cerrado vegetation, in relation to the CSI, which showed amplitudes lower than 0.08 in both areas.

Thus, it is possible to reinforce that the areas under pasture and eucalyptus, with eight years of implementation, with CMI greater than 100 at the studied depth, have adequate use in terms of $\mathrm{C}$ management.

These results corroborate those reported by Schiavo et al. (2011), who evaluated organic matter and soil aggregation and verified higher CMI values for pasture in comparison to annual crops.

\section{Conclusions}

1. Eucalyptus cultivation increases the contents and consequently the stocks of total organic carbon (TOC), as well as the $\mathrm{C}$ associated with minerals, equaling the area under native Cerrado vegetation.

2. Pasture cultivation accumulates particulate organic $\mathrm{C}$ up to a $20 \mathrm{~cm}$ depth and $\mathrm{C}$ associated with minerals up to $10 \mathrm{~cm}$.

3. The areas under pasture and eucalyptus have a positive effect on the $\mathrm{C}$ management index (CMI).

\section{ACKNowledgments}

Thanks to Conselho Nacional de Desenvolvimento Científico e Tecnológico - (CNPq), for the financial support given to the Research project 466137/2015-4 - Call MCTI/ CNPq/ANA No 23/2015 - Pesquisa em Mudança do Clima.

\section{Literature Cited}

Bayer, C.; Martin-Neto, L.; Mielniczulk, J.; Pavinato, A. Armazenamento de carbono em frações lábeis da matéria orgânica de um Latossolo Vermelho sob plantio direto. Pesquisa Agropecuária Brasileira, v.39, p.677-683, 2004. https://doi.org/10.1590/S0100204X2004000700009

Blair, G. J.; Lefroy, R. D. B.; Lisle, L. Soil carbon fractions based on their degree of oxidation, and the development of a carbon management index for agricultural systems. Australian Journal of Agricultural Research, v.46, p.1459-1466, 1995. https:/doi. org/10.1071/AR9951459

Cambardella, C. C.; Elliot, E. T. Particulate soil organic-matter changes across a grassland cultivation sequence. Soil Science Society of America Journal, v.3, p.777-783, 1992. https://doi.org/10.2136/ sssaj1992.03615995005600030017x

Costa, A. A.; Dias, B. de O.; Fraga; V. da S.; Santana, C. C.; Silva, N. da. Carbon and nitrogen stocks in soils under different forms of use in the Cerrado. Revista Brasileira de Engenharia Agrícola e Ambiental, v.24, p.528-533, 2020. http://dx.doi.org/10.1590/18071929/agriambi.v24n8p528-533

Costa, P. A. da; Mota, J. C. A.; Romero, R. E. Freire, A. G.; Ferreira, T. O. Changes in soil pore network in response to twenty-three years of irrigation in a tropical semiarid pasture from northeast Brazil. Soil \& Tillage Research, v.2, p.23-32, 2014. https://doi. org/10.1016/j.still.2013.11.004
Dona, F. D. de. Dinâmica da matéria orgânica do solo em sistemas irrigados por aspersão sob plantio direto e preparo convencional. Rio Grande do Sul: Universidade Federal do Rio Grande do Sul, 2005. 154p. Dissertação Mestrado

Dortzbach, D.; Pereira, M. G.; Blainski, E.; González, A. P. Estoque de $\mathrm{C}$ e abundância natural de ${ }^{13} \mathrm{C}$ em razão da conversão de áreas de floresta e pastagem em bioma mata atlântica. Revista Brasileira de Ciência do Solo, v.39, p.1643-1660, 2015. https:// doi.org/10.1590/01000683rbcs20140531

Ellert, B. H.; Janzer, H. H.; Mcconkey, B. G. Measuring and comparing soil carbon storage. In: Lal, R.; Kimbler, J. M.; Follet, R. F.; Stewart, B. A. Assessment methods for soil carbon. Florida: Boca Raton, 2001. Cap.10, p.131-146.

EMBRAPA - Empresa Brasileira de Pesquisa Agropecuária. Manual de métodos e análise de solo. 3.ed. Rio de Janeiro: Embrapa Solos, 2017. 573p.

Frazão, L. A.; Santana, I. K. da S.; Campos, D. V. B. de; Feigl, B. J.; Cerri, C. C. Estoque de carbono e nitrogênio e fração leve da matéria orgânica em Neossolo Quartzarênico sob uso agrícola. Pesquisa Agropecuária Brasileira, v.10, p.1198-1204, 2010. https:// doi.org/10.1590/S0100-204X2010001000020

Galdo, M. V.; Cerri, C. C.; Cerri, C. E. P. Soil carbono stocks under burned and unburned sugarcane in Brazil. Geoderma, v.153, p.347-352, 2009. https://doi.org/10.1016/j.geoderma.2009.08.025

Guareschi, R. F.; Pereira, M. G.; Perin, A. Estoque de carbono em latossolo vermelho distroférrico sob diferentes sistemas de manejo. Revista Brasileira de Ciências Agronômicas, v.7, p.597602, 2012. https://doi.org/10.5039/agraria.v7i4a1767

Guimarães, D. V.; Gonzaga, M. I. S.; Melo Neto, J. de O. Management of soil organic matter and carbon storage in tropical fruit crops. Revista Brasileira de Engenharia Agrícola e Ambiental, v.18, p.301306, 2014. https://doi.org/10.1590/S1415-43662014000300009

Guo, L. B.; Gifford, R. M. Soil carbon stocks and land use change: A meta analysis. Global Change Biology, v.8, p.345-360, 2002. https://doi.org/10.1046/j.1354-1013.2002.00486.x

Hickmann, C.; Costa, M. da. Estoque de carbono no solo e agregados em argissolo sob diferentes manejos de longa duração. Revista Brasileira de Engenharia Agrícola e Ambiental, v.16, p.1055-1061, 2012. https://doi.org/10.1590/S1415-43662012001000004

Lima, C. E. P.; Fontenelle, M. R.; Madeira, N. R.; Silva, J.; Guedes, I. M. R.; Silva, L. R. B.; Soares, D. C. Compartimento de carbono orgânico em latossolo cultivado com hortaliças sob diferentes manejos. Pesquisa Agropecuária Brasileira, v.51, p.378-387, 2016. https://doi.org/10.1590/S0100-204X2016000400011

Loss, A.; Pereira, M. G.; Schultz, N.; Anjos, L. H. C. dos; Silva, E. M. R. da. Frações orgânicas e índice de manejo de carbono do solo em diferentes sistemas de produção orgânica. IDESIA, v.2, p.1119, 2011. https://doi.org/10.4067/S0718-34292011000200002

Mendonça, V. Z. de; Mello, L. M. M. de; Andreotti, M.; Pereira, F. C. B. L.; Lima, R. C.; Valerio Filho, W. V.; Yano, E. H. Avaliação dos atributos físicos do solo em consórcio de forrageiras, milho em sucessão com soja em região de cerrados. Revista Brasileira de Ciência do Solo, v.37, p.251-259, 2013. https://doi.org/10.1590/ S0100-06832013000100026

Salimon, C. L.; Wadt, P. G. S.; Melo, A. W. F. de. Dinâmica do carbono na conversão de floresta para pastagem em argissolos da formação geológica Solimões no sudoeste da Amazônia. Revista de Biologia e Ciências da Terra, v.7, p.29-38, 2007. 
SAS - Statistical analysis system. SAS System for windows. version 9.1 Cary: Statistical Analysis System, 2003.

Schiavo, J. A.; Rosset, J. S.; Pereira, M. G.; Salton, J. C. Índice de manejo de carbono e atributos químicos de Latossolo Vermelho sob diferentes sistemas de manejo, Pesquisa Agropecuária Brasileira, v.46, p.1332-1338, 2011. https://doi.org/10.1590/S0100204X2011001000029

Srinivasan, V.; Maheswarappa, H. P.; Lal, R. Long term effects of topsoil depth and amendments on particulate and non particulate carbon fraction in a Miamian soil of Central Ohio. Soil \& Tillage Research, v.121, p.10-17, 2012. https://doi.org/10.1016/j. still.2012.01.014
Tesfaye, M. A.; Bravo, F.; Ruiz-Peinado, R.; Pando, V.; Bravo-Oviedo, A. Impact of changes in land use, species and elevation on soil organic carbon and total nitrogen in Ethiopian Central Highlands. Geoderma, v.261,p.70-79, 2016.https://doi.org/10.1016/j.geoderma.2015.06.022

Tchienkoua, M.; Zeach, W. Organic carbon and plant nutrient dynamics under three land uses in the highlands of West Camerron. Agriculture, Ecosystems \& Environment, v.104, p.673679, 2004. https://doi.org/10.1016/j.agee.2003.10.007

Vieira, F. C. B.; Bayer, C.; Zanatta, J. A.; Mielniczuk, J.; Six, J. Building up organic matter in a subtropical Paleudult under legume covercrop-based rotations. Soil Science Society of America Journal, v.73, p.1699-1706, 2009. https://doi.org/10.2136/sssaj2008.0241 